ISSN 1392-3196 / e-ISSN 2335-8947

Zemdirbyste-Agriculture, vol. 105, No. 4 (2018), p. 331-338

DOI $10.13080 / \mathrm{z}-\mathrm{a} .2018 .105 .042$

\title{
The impact of non-chemical weed control methods on the disease occurrence in the organically grown winter oilseed rape crop
}

\author{
Aušra MARCINKEVIČIENE ${ }^{1}$, Rimantas VELIČKA ${ }^{1,2}$, Lina Marija BUTKEVIČIENË $\dot{L}^{1,2}$, \\ Marina KEIDAN ${ }^{1}$, Rita PUPALIENE ${ }^{1}$, Zita KRIAUČIŪNIENE ${ }^{1,2}$, Robertas KOSTECKAS ${ }^{2}$, \\ Sigitas ČEKANAUSKAS ${ }^{2}$, Steponas RAUDONIUS ${ }^{1}$
}

${ }^{1}$ Aleksandras Stulginskis University

Studentų 11, Akademija, Kaunas distr., Lithuania

E-mail: ausra.marcinkeviciene@asu.lt

${ }^{2}$ Experimental Station, Aleksandras Stulginskis University

Rapsų 7, Noreikiškès, Kaunas distr., Lithuania

\begin{abstract}
Oilseed rape cultivation under organic farming conditions presents a high risk of increased incidence of weeds, pests and diseases, resulting in low rapeseed yielding capacity. The current study aimed to estimate the effects of nonchemical weed management methods: thermal, mechanical and self-regulation (natural weed / crop competition), on the incidence of fungal diseases in winter oilseed rape (Brassica napus L.) stands and on rapeseed yield in the organic production system. A field experiment was conducted in 2014-2017 at Aleksandras Stulginskis University's Experimental Station. The soil of the experimental site is Endocalcaric Endogleyic Luvisol (LV-can.gln).

Under less favourable conditions for the occurrence of phoma stem canker, both thermal and mechanical weed control methods were shown to inhibit the spread of the disease in the oilseed rape crop compared with the selfregulation weed control treatment. However, under the conditions conducive to the spread of phoma stem canker, only mechanical weed control method in combination with the bio-preparations proved to be effective. In 2015 and 2016 , the lowest incidence of the verticillium wilt was recorded in the oilseed rape plots where weeds had been managed by steaming. In 2017 significantly, from 2.3 to 3.3 times lower number of verticillium wilt-affected stems was determined in the mechanical weed control plots as compared with that in the plots where other weed control methods had been applied. Application of bio-preparations decreased the number of verticillium wilt-affected stems by on average 11.1$15.6 \%$. The lowest incidence of dark leaf and pod spot was established in the plots where weeds had been controlled by water steam and no bio-preparations had been used. The bio-preparations were found to increase the severity of dark leaf and pod spot on oilseed rape siliques by on average 13.1-79.4\%. Significantly the highest rapeseed yield in 2015 and significantly higher compared with self-regulation in 2017 was recorded in the mechanical weed control treatment, while in 2016 the highest rapeseed yield was established in the self-regulation treatment applied with the bio-preparations. In 2017, the verticillium wilt severity in the winter oilseed rape crop was found to negatively, strongly and statistically significantly correlate with rapeseed yield $\left(r^{2}=0.69, P<0.05\right)$.
\end{abstract}

Key words: bio-preparations, Brassica napus, diseases, organic cropping, rapeseed yield, weed management methods.

\section{Introduction}

The idea of organic farming began to spread throughout the world in the early eighties of the $20^{\text {th }}$ century. The development of organic farming was prompted by the environmental concern, health issues, and the search for solutions to social problems. The cultivation of oilseed rape and turnip rape on organically managed farms was encouraged by a search for healthy, high quality and safe food. The area of organically cultivated oilseed rape and turnip rape in the world amounted to approximately 93 thousand hectares (The World of Organic Agriculture..., 2017). According to the data from the public institution "Ekoagros", in 2017 the total area devoted to oilseed rape production in organically managed farms in Lithuania amounted to 3962.2 ha, including 3250.98 ha of winter oilseed rape and 711.22 ha of spring oilseed rape. In 2017, the yield of spring oilseed rape averaged $0.52 \mathrm{tha}^{-1}$ and that of winter oilseed rape averaged $1.63 \mathrm{t} \mathrm{ha}^{-1}$. Growing of oilseed rape under organic production conditions poses a serious risk of increased incidence of weeds, pests and diseases, resulting in low rapeseed yields (Valantin-Morison, Meynard, 2008). Therefore, the area devoted to rapeseed production in organic farms is small. Oerke (2006) indicates that the yield losses of agricultural crops due to weeds account for $34 \%$, while the yield losses to pests and diseases account for $18 \%$ and $16 \%$. Under organic production system, which bans the use of synthetic pesticides, the crop yield losses are even higher (Walters, 2009).

Phoma stem canker (Leptosphaeria spp.) is a globally important devastating fungal disease of oilseed

Please use the following format when citing the article:

Marcinkevičienė A., Velička R., Butkevičienė L. M., Keidan M., Pupalienė R., Z. Kriaučiūnienè R., Kosteckas R., Čekanauskas S., Raudonius S. 2018. The impact of non-chemical weed control methods on the disease occurrence in the organically grown winter oilseed rape crop. Zemdirbyste-Agriculture, 105 (4): 331-338. DOI 10.13080/z-a.2018.105.042 
rape which is being widely investigated worldwide (Aubertot, 2006; Liu et al., 2006; Brazauskienè et al., 2007; Bankina et al., 2012; Liu et al., 2014; Fernando et al., 2016; Hegewald et al., 2017; Mazáková et al., 2017; Cai et al., 2018). The pathogen populations of phoma stem canker comprise two species, Leptosphaeria maculants (group A) and L. biglobosa (group B). L. maculants causes severe damage to stem base of oilseed rape plants, while L. biglobosa causes damage to leaves and produces upper stem lesions (Liu et al., 2006; Dabkevičius, Brazauskiene, 2007; Liu et al., 2014; Cai et al., 2018). Brazauskienè et al. (2012) have found that the incidence and severity of phoma stem canker are influenced by the seasonal type of oilseed rape (winter or spring), state of the crop and the meteorological conditions. Winter oilseed rape was more susceptible to phoma stem canker than spring oilseed rape. When the weather is warm during the autumn growing season, the conditions for the maturation of L. maculants pseudothecia and dispersal of ascospores and winter oilseed rape infection in the autumn are much more favourable. When the incidence of phoma stem canker on oilseed rape leaves in the autumn is high, the disease incidence on stems the following year is generally more than $90 \%$ higher (Brazauskiene et al., 2007). Liu et al. (2006) have documented that when the weather in August and September is dry, the dispersal of ascospores starts only in November. For this reason, the phoma stem canker infection pressure in oilseed rape crops in the autumn is lower. Cai et al. (2018) have found that depending on the meteorological conditions, rapeseed yield losses to phoma stem canker range from $10 \%$ to $37 \%$. With increasing oilseed rape concentration in the crop rotations, phoma stem canker incidence and severity in the crops increase even more (Hegewald et al., 2017).

In recent years, the increasing oilseed rape area in crop rotations has resulted in a marked surge in the occurrence of another harmful oilseed rape disease, verticillium wilt (Verticillium spp.), caused by the Verticillium longisporum fungus (Berg et al., 2006; Dunker et al., 2008; Lelešius et al., 2016; Spitzer, Matušinsky, 2017). The spread of the latter disease is considerably influenced by the soil temperature and oilseed rape cultivar grown (Dunker et al., 2008). Berg et al. (2006) have shown that the rapeseed losses to verticillium wilt can range from $30 \%$ to $50 \%$. Dunker et al. (2008) suggest that yield losses per individual plant vary from $20 \%$ to $80 \%$.

Dark leaf and pod spot, caused by the Alternaria brassicacae fungus, is a common disease in oilseed rape crops (Brazauskienè et al., 2011 a; Bankina et al., 2012; Kumar et al., 2014). The spread of the latter disease in agricultural crops is markedly affected by the relative air humidity, temperature and amount of rainfall (Brazauskienè et al., 2011 a; Kumar et al., 2014). Bankina et al. (2012) have demonstrated that dark leaf and pod spot is identified annually, but its severity is generally low. Due to intensive spread of dark leaf and pod spot, the yield losses of the Brassicaceae family plants can fluctuate from $32 \%$ to $57 \%$ (Shrestha et al., 2005).

Under the conditions of organic cropping, the control of the spread of disease causal agents in agricultural crops puts particular emphasis on crop rotations, tillage, choice of disease resistant cultivars, sowing time, crop density, and timely weed control (Aubertot et al., 2006). In weed-infested oilseed rape crops, the plants tend to be weaker and less resistant to various disease causal agents. In addition, weeds, particularly broad-leaved ones, provide a living space for fungal disease pathogens (Walters, 2009). In organically managed farms, weeds occurring in oilseed rape crops can be exterminated using mechanical and thermal control methods when growing the crops with wide inter-rows (Kierzek et al., 2008; Peltzer et al., 2009). Cultivation of oilseed rape crops with wide inter-rows and high plant density per row reduced seed germination and increased disease occurrence (Peltzer et al., 2009). Weed control in agricultural crops using water steam treatment has been shown to reduce the incidence of fungal diseases (Brazienè, Vasinauskienè, 2011).

In organic production farms, where fungicide spray application on oilseed rape crops is not allowed, more heed should be paid to bio-preparations (Kurowski et al., 2009; Błaszczyk et al., 2014; Kumar et al., 2014; Szczepanek et al., 2016). Bulgari et al. (2015) suggest that bio-preparations (amino acids) improve the growth of agricultural crops and their resistance to adverse environmental factors, improve plant photosynthetic intensity, resistance to bacteria, fungi and viruses and enhance crop productivity. The effects of biopreparations on the productivity of various agricultural crops under Lithuania's climate conditions have been more comprehensively studied by Jakienè (2013), Jakienè and Spruogis (2015) and Pekarskas et al. (2017). Research has shown that the use of bio-preparations reduced the incidence and development of microscopic fungi (Sinkevičienè et al., 2015). However, few studies have investigated the use of bio-preparations in oilseed rape crops.

It has been hypothesized that different nonchemical weed control methods in combination with bio-preparations increase the resistance of winter oilseed rape to the pathogens of fungal diseases and enhance rapeseed yield in the organic production system.

The objective of the current study was to determine the effects of the non-chemical weed control methods (thermal, mechanical, and self-regulation (natural weed / crop competition)) on the occurrence of fungal diseases (phoma stem canker, verticillium wilt and dark leaf and pod spot) in the winter oilseed rape crop and on rapeseed yield under organic production system.

\section{Materials and methods}

A field experiment was conducted in 2014 2017 at the Experimental Station $\left(54^{\circ} 53^{\prime} \mathrm{N}, 23^{\circ} 50^{\prime} \mathrm{E}\right)$ of Aleksandras Stulginskis University on an Endocalcaric Endogleyic Luvisol ( $L V$-can.gln) according to the WRB 2014. Agrochemical properties of the experimental soil (averaged data of 2014, 2015 and 2016) were as follows: soil $\mathrm{pH}-7.30$, humus $-1.79 \%$, content of available nutrients in the soil: $\mathrm{P}_{2} \mathrm{O}_{5}-199.0 \mathrm{mg} \mathrm{kg}^{-1}, \mathrm{~K}_{2} \mathrm{O}-97.7 \mathrm{mg}$ $\mathrm{kg}^{-1}$. The experiment included the following treatments: factor A - non-chemical weed control methods: 1) thermal (water steam), 2) mechanical (inter-row cultivation) and 3) self-regulation (natural weed / crop competition, sowing with narrow inter-rows); factor B - use of bio-preparations: 1) without bio-preparations and 2) with bio-preparations.

A Swedish winter oilseed rape (Brassica napus L. spp. oleifera biennis Metzg.) cultivar 'Cult' was grown in the experiment. In 2014, the crop was sown on $1^{\text {st }}$ September, in 2015 on $27^{\text {th }}$ August and in 2016 on $29^{\text {th }}$ August using a sowing machine MultiDrill M 300 (Germany). The crop was sown at a seed rate of $3 \mathrm{~kg} \mathrm{ha}^{-1}$ in all experimental plots. In the plots where mechanical and thermal weed control was applied, winter oilseed rape was grown with $48 \mathrm{~cm}$ wide inter-rows (sowing was performed every fourth row by closing three seeding tubes in the spaces between). In the plots where thermal weed control was used, weeds were killed by a mobile thermal (water steam) weed control unit (thermal power $90 \mathrm{~kW}$, capacity $120 \mathrm{~kg} \mathrm{~h}^{-1}$ steam, fuelled by liquefied gas). The steam temperature was $99^{\circ} \mathrm{C}$; the thermal treatment time was 2 seconds; approximately $2 \mathrm{~mm}$ of the soil layer was heated up (Sirvydas, Kerpauskas, 2012). In the plots where mechanical weed control was applied, the inter-rows were cultivated by a soil cultivator KOR- 
4.2-01 (Ukraine) with duck-foot coulters. Two passes by the cultivator were made. Thermal and mechanical weed control methods were applied twice: in the autumn at 3-4 leaf growth stage (BBCH 13-14) of winter oilseed rape and after resumption of vegetation in the spring (BBCH 50). In the self-regulation weed control treatment oilseed rape was grown with $12 \mathrm{~cm}$ wide inter-rows. For the treatments with the use of bio-preparations, the seeds before sowing were coated with the bio-organic fertilizer Nagro (BioPlant) (0.5 L per ton of seed and $10 \mathrm{~L}$ of water) $\left(9.09 \mathrm{~g} \mathrm{~L}^{-1}\right.$ humic and fulvic acids, $0.35 \mathrm{~g} \mathrm{~L}^{-1} \mathrm{~N}, 0.73 \mathrm{~g} \mathrm{~L}^{-1} \mathrm{P}, 2.49 \mathrm{~g} \mathrm{~L}^{-1} \mathrm{~K}$, $283.8 \mathrm{mg} \mathrm{L}^{-1} \mathrm{Mg}, 0.36 \mathrm{mg} \mathrm{L}^{-1} \mathrm{~B}, 0.90 \mathrm{mg} \mathrm{L}^{-1} \mathrm{Cu}, 110.5 \mathrm{mg}$ $\mathrm{L}^{-1} \mathrm{Fe}, 435.7 \mathrm{mg} \mathrm{L}^{-1} \mathrm{Mn}, 713.1 \mathrm{mg} \mathrm{L}^{-1} \mathrm{Mo}, 345.5 \mathrm{mg} \mathrm{L}^{-1}$ $\mathrm{Zn}, 51.95 \mathrm{mg} \mathrm{L}^{-1} \mathrm{Co}, 0.138 \mathrm{mg} \mathrm{L}^{-1} \mathrm{Se}, 0.231 \mathrm{mg} \mathrm{L}^{-1} \mathrm{Cd}$, $0.02 \mathrm{mg} \mathrm{L}^{-1} \mathrm{Cr}, 1.30 \mathrm{mg} \mathrm{L}^{-1} \mathrm{Ni}, 9.09 \mathrm{~g} \mathrm{~L}^{-1}$ organic matter, $4.60 \mathrm{~g} \mathrm{~L}^{-1}$ organic carbon), during the vegetation season the crop was sprayed twice with the bio-preparations (in the autumn with Terra Sorb Foliar (Biolberica) (9.3\% free aminoacids, $2.1 \% \mathrm{~N}, 0.019 \% \mathrm{~B}, 0.046 \% \mathrm{Mn}$, $0.067 \% \mathrm{Zn})\left(2 \mathrm{~L} \mathrm{ha}^{-1}\right)$, in the spring with Terra Sorb Foliar $\left(1 \mathrm{~L} \mathrm{ha}^{-1}\right)$ and $0.3 \%$ Konflic (Atlantica Agricola) $(50 \%$ extract of Quassia amara, 50\% potassium soap of oleic acid of natural origin and $85 \%$ organic matter). Synthetic fertilizers and chemical plant protection products were not used in the experiment. In 2015, winter oilseed rape was harvested on $27^{\text {th }} \mathrm{July}$, in 2016 on $20^{\text {th }}$ July and in 2017 on $28^{\text {th }}$ July.

The total size of a plot was $84 \mathrm{~m}^{2}$ and that of a harvested plot $20 \mathrm{~m}^{2}$. The experiments included four replications. The pre-crop was bare fallow, in the autumn the fallow was ploughed and several times cultivated and harrowed before winter oilseed rape sowing. A split-plot experimental design was used. Nonchemical weed control methods (factor A) were used on the main plots and bio-preparations (factor B) were applied on sub-plots. Agrochemical properties of the soil were determined before sowing. The soil was sampled from each experimental plot at 15 random locations with a soil auger from the $0-25 \mathrm{~cm}$ layer. The soil $\mathrm{pH}$ was measured potentiometrically in $1 \mathrm{~N} \mathrm{KCl}$ extract, available phosphorus $\mathrm{P}_{2} \mathrm{O}_{5}$ and potassium $\mathrm{K}_{2} \mathrm{O}\left(\mathrm{mg} \mathrm{kg}^{-1}\right.$ soil) were estimated by the Egner-Riehm-Domingo (A-L) method, organic carbon was established using a Heraeus analyser (Germany) by combusting the samples at $900^{\circ} \mathrm{C}$ temperature. Humus content was calculated by multiplying organic carbon content by a coefficient 1.724. Soil samples were analysed at Lithuanian Research Centre for Agriculture and Forestry's Agrochemical Research Laboratory. Winter oilseed rape growth stages were described according to BBCH scale (Meier, 2001).

Phoma stem canker in winter oilseed rape plots was assessed at the $\mathrm{BBCH} 85$ growth stage of oilseed rape. Phoma stem canker was assessed on 30 plants per each plot, i.e. 10 plants from three spots. Phoma stem canker damage was estimated on the stems of winter oilseed rape plants. Percentage of disease-affected stems from the total number of assessed stems was calculated. The severity of phoma stem canker was estimated by cross-sectioning the stems in the root neck area and $5 \mathrm{~cm}$ above the root neck according to the scale: 1 - no disease symptoms, 2 - less than $10 \%$ of the cross-sectioned stem girdled by lesion, $3-10-25 \%$ of the cross-sectioned stem girdled by lesion, $4-25-50 \%$ of the cross-sectioned stem girdled by lesion, 5 - more than $50 \%$ of the crosssectioned stem girdled by lesion, 6 - dead plant.

The disease severity index (DSI) was calculated according to the formula (Kuusk et al., 2002):

$\mathrm{DS}=(0 \times n 1)+(1 \times n 2)+(3 \times n 3)+(5 \times n 4)+$ $(7 \times n 5)+(9 \times n 6) /$ total number of assessed plants (1), where $n 1,2,3 \ldots$ is number of plants within each specific score.

Verticillium wilt spread in winter oilseed rape crop was evaluated after harvesting by examining 30 stubbles of oilseed rape in randomly selected places of each treatment plot. Percentage of verticillium affected stems from the total number of examined stems was estimated (Dunker et al., 2008).

Dark leaf and pod spot was assessed on arbitrarily chosen 100 siliques per plot. The disease severity on siliques was assessed according to the scale: 0 - no infection, 1 - little damage, 5 - up to $5 \%$ of silique area covered by the disease, $10-$ up to $10 \%$ of silique area covered by the disease, 20 - on average $11-25 \%$ of silique area covered by the disease, 30 - severe damage $26-50 \%$ of silique area covered by the disease, $50-$ very severe damage $>50 \%$ of silique area covered by the disease (Conn et al., 1990). The disease severity was calculated according to the formula (Žemès ūkio augalu kenkèjai..., 2002):

$$
R=\frac{\sum(n \times b)}{N}
$$

where $R$ is disease severity, $\sum(n \times b)$ - the number of siliques within infection grade and the sum of products of numerical value of each grade, $N$ - the total number of inspected siliques. Dark leaf and pod spot was assessed at the BBCH 79 growth stage of oilseed rape.

Rapeseed yield was calculated as of a standard $8.5 \%$ moisture and absolutely clean seed $\left(\mathrm{kg} \mathrm{ha}^{-1}\right)$.

Data of the research was statistically analysed by two-way SPLIT-PLOT analysis of variance ( $A N O V A)$ for the quantitative indices, and correlation and regression methods (Raudonius, 2017). The significance of the differences between the treatments was evaluated applying $F$ criteria and the least significant difference (LSD) test. The data of fungal diseases that did not fit the normal distribution, were transformed by $y=\ln (x)$ prior to the statistical estimation. Significant interaction among the tested factors and seasons was established; therefore no data averages are presented.

Meteorological conditions. In 2014, autumn was warm and long, therefore conditions for winter oilseed rape growth were favourable (Fig. 1).

In 2015, the weather conditions for oilseed rape wintering were also favourable. The snow cover was not thin. Spring started early and was warm. Therefore the plants resumed vegetation within the first ten-day period of the month. June and August were warm and dry, the monthly hydrothermal coefficient (HTC) was 0.35 (dry) and 0.11 (very dry) respectively. Autumn was also warm and long.

In 2016, very cold weather set in within the first ten-day period of January and there was no snow cover which resulted in winter-kill of part of the crop. The average air temperatures of February, March and April were higher than the long-term average. In 2016, winter oilseed rape plants resumed vegetation on $4^{\text {th }}$ April. May was warm, with a HTC of 1.09 (optimal irrigation). June, May and August were warm and humid. September was warm and dry, but October and November were cool and rainy. The temperatures of December, January and February were higher than the long-term average. The average monthly temperature of March was $4.4^{\circ} \mathrm{C}$ higher than the long-term average.

In 2017, oilseed rape plants resumed vegetation on $31^{\text {st }}$ March. April was cold and wet. Due to this reason, part of the oilseed rape crop damped off. May was warm and HTC was 0.29 (very dry). June and July were cool, HTC was 1.78 (excess irrigation) and 1.53 (optimal irrigation), respectively.

\section{Results and discussion}

Phoma stem canker damage. Our study showed that phoma stem canker developed from stem lesions at the root collar or crown of oilseed rape plants. In 2015, at the growth stage $\mathrm{BBCH} 85$, the stems affected by phoma 

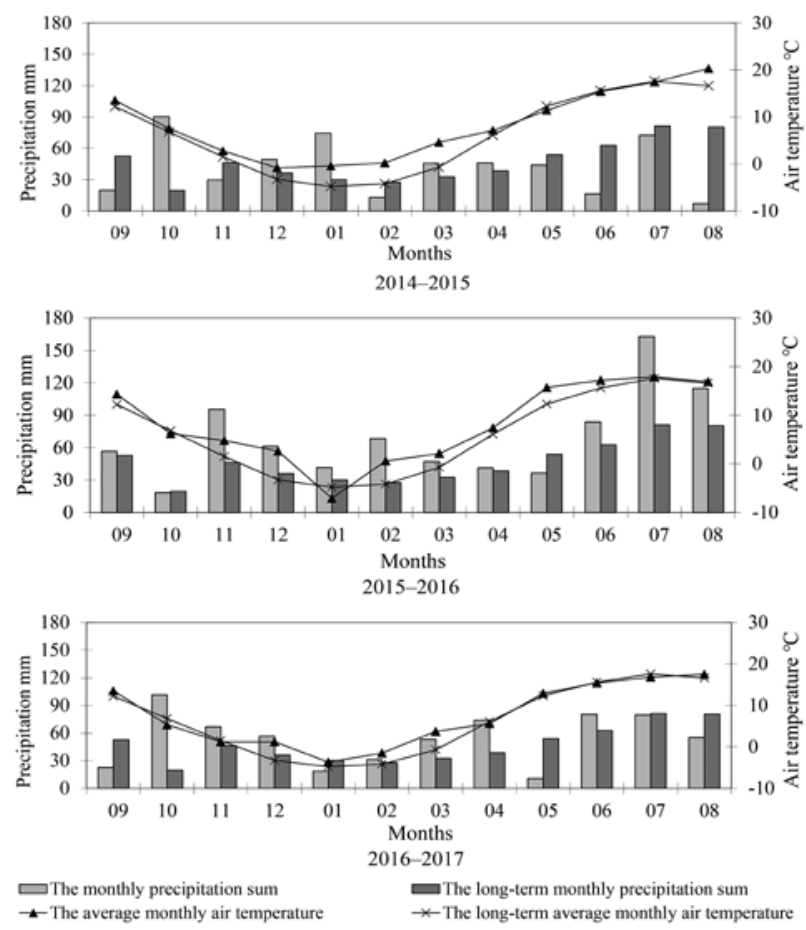

Figure 1. Meteorological conditions during the winter oilseed rape vegetation season (2014-2017) (Kaunas Meteorological Station)

stem canker accounted for $33.6-61.8 \%$ of the total tested (Table 1). The disease severity index ranged from 1.15 to 1.83 . Brazauskiene et al. (2011 b) have reported that before harvesting the phoma stem canker-affected stems accounted for $48-72 \%$. The disease damage level for most of the stems inspected (from $36.6 \%$ to $57.2 \%$ ) was estimated by score 2 : less than $10 \%$ of the stem parameter girdled by the phoma stem canker lesions. In the plots with inter-row cultivation but without the use of the bio-preparations the number of disease-affected stems and the disease severity index were found to be significantly by respectively $35.1 \%$ and $25.1 \%$ lower than for the self-regulation treatment. With the use of the biopreparations in the thermal (water steam) weed control treatment, the number of the disease-affected stems and the disease severity index were shown to be significantly by respectively $36.6 \%$ and $28.1 \%$ lower than that in the self-regulation treatments. As reported by Vasinauskienè and Braziene (2017), the water steam reduces the development of fungal diseases in agricultural crops. The use of the bio-preparations, compared with no use, did not have significant effect on the spread of phoma stem canker in the winter oilseed rape crop.

In 2016, with the amount of rainfall in July $81.7 \mathrm{~mm}$ higher than usual, the number of phoma stem canker-affected rape stems was found to be 1.1-2.1 times higher and the disease severity index 1.5-3.8 times higher than in 2015. In 2016, the phoma stem cankeraffected stems accounted for $57.5-85.8 \%$ and the disease severity index ranged from 2.28 to 4.32 . In the thermal weed control treatment without the use of the biopreparations, significantly lower number of the disease affected stems and disease severity index by respectively $17.9 \%$ and $25.8 \%$ and $30.9 \%$ and $44.1 \%$ were determined than in the mechanical and self-regulation weed control plots. With the use of the bio-preparations, significantly $18.8 \%$ and $24.2 \%$ lower number of the disease affected stems and $44.0 \%$ and $43.5 \%$ lower disease severity index were recorded in the self-regulation plots, compared with the thermal and mechanical weed control treatments. According to the disease damage, the stems were scored 2 (less than $10 \%$ of stem perimeter girdled by phoma stem canker lesions) and $3(10-25 \%$ of stem per meter girdled with the disease lesions) and 6 (dead leaves) from $19.0 \%$ to $39.0 \%$, from $16.2 \%$ to $22.9 \%$ and from $10.2 \%$ to $31.1 \%$, respectively.

Without the bio-preparations, significantly $35.0 \%$ lower disease damage score (2) was identified in the self-regulation plots, compared with the thermal weed control treatment. In the thermal and mechanical weed control treatments with the use of the bio-preparations, the number of stems with a disease damage score value 2 was significantly $51.3 \%$ and $37.9 \%$, respectively lower compared with the self-regulation treatment. Without the bio-preparations, significantly $43.4 \%$ and $34.9 \%$ lower number of oilseed rape stems with a disease damage score value 6 was established in the mechanical and thermal weed control treatments, compared with the self-regulation treatment. However, with the use of the bio-preparations, self-regulation proved to be more effective, compared with the thermal and mechanical weed control treatments, the number of stems with a disease damage score value

Table 1. The incidence of phoma stem canker in the winter oilseed rape crop (2015-2017)

\begin{tabular}{|c|c|c|c|c|c|c|c|c|}
\hline \multirow{2}{*}{$\begin{array}{l}\text { Weed control } \\
\text { method } \\
\text { (factor A) }\end{array}$} & \multirow{2}{*}{$\begin{array}{l}\text { Application of } \\
\text { bio-preparations } \\
\text { (factor B) }\end{array}$} & \multirow{2}{*}{$\begin{array}{c}\text { Damaged } \\
\text { stems } \\
\% \\
\end{array}$} & \multirow{2}{*}{$\begin{array}{l}\text { Disease } \\
\text { severity } \\
\text { index }\end{array}$} & \multicolumn{5}{|c|}{$\begin{array}{l}\text { Distribution \% of damaged stems } \\
\text { according to phoma severity score }\end{array}$} \\
\hline & & & & 2 & 3 & 4 & 5 & 6 \\
\hline \multicolumn{9}{|c|}{2015} \\
\hline Thermal & $\begin{array}{l}- \\
+ \\
\end{array}$ & $\begin{array}{l}40.9 \mathrm{ab} \\
39.2 \mathrm{~b}\end{array}$ & $\begin{array}{l}1.47 \mathrm{ab} \\
1.15 \mathrm{~b} \\
\end{array}$ & $\begin{array}{l}34.8 \mathrm{a} \\
43.5 \mathrm{a} \\
\end{array}$ & $\begin{array}{l}21.7 \mathrm{a} \\
30.4 \mathrm{a} \\
\end{array}$ & $\begin{array}{l}17.4 \mathrm{a} \\
6.50 \mathrm{a} \\
\end{array}$ & $\begin{array}{l}10.9 \mathrm{a} \\
10.9 \mathrm{a}\end{array}$ & $\begin{array}{l}15.2 \mathrm{a} \\
8.70 \mathrm{a} \\
\end{array}$ \\
\hline Mechanical & $\begin{array}{l}- \\
+ \\
\end{array}$ & $\begin{array}{r}33.6 \mathrm{~b} \\
44.4 \mathrm{ab} \\
\end{array}$ & $\begin{array}{l}1.37 \mathrm{~b} \\
1.49 \mathrm{ab} \\
\end{array}$ & $\begin{array}{l}46.6 \mathrm{a} \\
57.2 \mathrm{a}\end{array}$ & $\begin{array}{l}11.6 \mathrm{a} \\
10.7 \mathrm{~b}\end{array}$ & $\begin{array}{l}11.6 \mathrm{a} \\
8.90 \mathrm{a}\end{array}$ & $\begin{array}{l}18.6 \mathrm{a} \\
7.10 \mathrm{a} \\
\end{array}$ & $\begin{array}{l}11.6 \mathrm{a} \\
16.1 \mathrm{a} \\
\end{array}$ \\
\hline Self-regulation & $\begin{array}{l}- \\
+\end{array}$ & $\begin{array}{l}51.8 \mathrm{a} \\
61.8 \mathrm{a}\end{array}$ & $\begin{array}{l}1.83 \mathrm{a} \\
1.60 \mathrm{a}\end{array}$ & $\begin{array}{l}36.6 \mathrm{a} \\
52.2 \mathrm{a}\end{array}$ & $\begin{array}{r}23.8 \mathrm{a} \\
21.7 \mathrm{ab}\end{array}$ & $\begin{array}{l}20.6 \mathrm{a} \\
11.6 \mathrm{a}\end{array}$ & $\begin{array}{l}6.30 \mathrm{a} \\
8.70 \mathrm{a}\end{array}$ & $\begin{array}{l}12.7 \mathrm{a} \\
5.80 \mathrm{a}\end{array}$ \\
\hline \multicolumn{9}{|c|}{2016} \\
\hline Thermal & $\begin{array}{l}- \\
+\end{array}$ & $\begin{array}{l}57.5 \mathrm{~b}^{*} \\
80.0 \mathrm{a}^{*}\end{array}$ & $\begin{array}{l}2.28 \mathrm{~b}^{*} \\
4.32 \mathrm{a}^{*}\end{array}$ & $\begin{array}{l}38.9 \mathrm{a}^{*} \\
19.0 \mathrm{~b}^{*}\end{array}$ & $\begin{array}{l}22.6 \mathrm{a} \\
22.5 \mathrm{a} \\
\end{array}$ & $\begin{array}{l}8.15 \mathrm{~b} \\
9.68 \mathrm{a} \\
\end{array}$ & $\begin{array}{l}13.6 \mathrm{a} \\
17.7 \mathrm{a} \\
\end{array}$ & $\begin{array}{l}16.7 \mathrm{~b}^{*} \\
31.1 \mathrm{a}^{*}\end{array}$ \\
\hline Mechanical & $\begin{array}{l}- \\
+\end{array}$ & $\begin{array}{l}70.0 \mathrm{a}^{*} \\
85.8 \mathrm{a}^{*}\end{array}$ & $\begin{array}{l}3.30 \mathrm{a}^{*} \\
4.28 \mathrm{a}^{*}\end{array}$ & $\begin{array}{l}27.2 \mathrm{ab} \\
24.2 \mathrm{~b}\end{array}$ & $\begin{array}{l}17.0 \mathrm{a} \\
18.2 \mathrm{a}\end{array}$ & $\begin{array}{l}17.7 \mathrm{a} \\
14.4 \mathrm{a}\end{array}$ & $\begin{array}{l}19.0 \mathrm{a} \\
18.8 \mathrm{a}\end{array}$ & $\begin{array}{l}19.2 \mathrm{~b} \\
24.5 \mathrm{~b}\end{array}$ \\
\hline Self-regulation & $\begin{array}{l}- \\
+ \\
\end{array}$ & $\begin{array}{l}77.5 \mathrm{a}^{*} \\
65.0 \mathrm{~b}^{*} \\
\end{array}$ & $\begin{array}{l}4.08 \mathrm{a}^{*} \\
2.42 \mathrm{~b}^{*} \\
\end{array}$ & $\begin{array}{l}25.3 \mathrm{~b}^{*} \\
39.0 \mathrm{a}^{*} \\
\end{array}$ & $\begin{array}{r}16.2 \mathrm{a} \\
22.9 \mathrm{a} \\
\end{array}$ & $\begin{array}{l}10.5 \mathrm{~b} \\
12.7 \mathrm{a} \\
\end{array}$ & $\begin{array}{l}18.5 \mathrm{a} \\
15.3 \mathrm{a} \\
\end{array}$ & $\begin{array}{l}29.5 \mathrm{a}^{*} \\
10.2 \mathrm{c}^{*}\end{array}$ \\
\hline \multicolumn{9}{|c|}{2017} \\
\hline Thermal & $\begin{array}{l}- \\
+ \\
\end{array}$ & $\begin{array}{l}91.7 \mathrm{a} \\
97.5 \mathrm{a} \\
\end{array}$ & $\begin{array}{l}6.02 \mathrm{a} \\
6.06 \mathrm{a} \\
\end{array}$ & $\begin{array}{l}3.52 \mathrm{a} \\
2.97 \mathrm{a} \\
\end{array}$ & $\begin{array}{l}3.17 \mathrm{a} \\
3.53 \mathrm{a} \\
\end{array}$ & $\begin{array}{l}8.45 \mathrm{a}^{*} \\
15.4 \mathrm{a}^{*} \\
\end{array}$ & $\begin{array}{l}24.2 \mathrm{a} \\
29.9 \mathrm{a} \\
\end{array}$ & $\begin{array}{l}44.0 \mathrm{a} \\
31.6 \mathrm{a} \\
\end{array}$ \\
\hline Mechanical & $\begin{array}{l}- \\
+\end{array}$ & $\begin{array}{l}92.5 \mathrm{a} \\
83.4 \mathrm{~b}\end{array}$ & $\begin{array}{l}5.04 \mathrm{a} \\
4.72 \mathrm{~b}\end{array}$ & $\begin{array}{l}4.88 \mathrm{a} \\
4.16 \mathrm{a}\end{array}$ & $\begin{array}{l}3.22 \mathrm{a} \\
4.13 \mathrm{a}\end{array}$ & $\begin{array}{l}9.05 \mathrm{a} \\
8.00 \mathrm{~b}\end{array}$ & $\begin{array}{l}29.5 \mathrm{a} \\
30.5 \mathrm{a}\end{array}$ & $\begin{array}{l}26.0 \mathrm{~b} \\
25.2 \mathrm{a}\end{array}$ \\
\hline Self-regulation & $\begin{array}{l}- \\
+ \\
\end{array}$ & $\begin{array}{l}96.7 \mathrm{a} \\
91.7 \mathrm{a} \\
\end{array}$ & $\begin{array}{l}6.05 \mathrm{a} \\
5.65 \mathrm{a} \\
\end{array}$ & $\begin{array}{l}3.30 \mathrm{a} \\
3.50 \mathrm{a}\end{array}$ & $\begin{array}{l}3.64 \mathrm{a} \\
3.81 \mathrm{a} \\
\end{array}$ & $\begin{array}{l}8.68 \mathrm{a} \\
10.1 \mathrm{~b}\end{array}$ & $\begin{array}{l}30.9 \mathrm{a} \\
27.2 \mathrm{a} \\
\end{array}$ & $\begin{array}{c}34.6 \mathrm{ab} \\
35.3 \mathrm{a}\end{array}$ \\
\hline
\end{tabular}

Note. - - without, + - with application; the differences between the averages of treatments of factor A at one level of factor B, marked by not the same letter $(\mathrm{a}, \mathrm{b}, \mathrm{c})$, and between the averages of treatments of factor $\mathrm{B}$, marked by an asterisk are significant $(P<0.05) ;{ }^{\#}-$ severity score scale is described in Material and methods. 
6 was significantly $67.2 \%$ and $58.4 \%$ lower. The use of the bio-preparations, compared with no use, significantly increased phoma stem canker-affected rape stems and the disease severity index in the thermal and mechanical weed control treatments by respectively $39.1 \%$ and $89.5 \%$ and $22.6 \%$ and $29.7 \%$, whereas in the self-regulation treatment the use of bio-preparations significantly reduced these parameters by respectively $16.1 \%$ and $40.7 \%$. The use of the bio-preparations in the thermal weed control treatment significantly by $51.2 \%$ reduced the number of stems with a disease score value 2 ; however, it significantly by $86.2 \%$ increased the number of stems with a disease score value 6 . The use of the bio-preparations in the self-regulation treatment significantly by $54.2 \%$ increased the number of stems with a disease score value 2 ; however, it gave a significant $65.4 \%$ reduction in the number of stems with a disease score value 6. Kurowski et al. (2009) have found that bio-preparations reduced the occurrence of fungal diseases in oilseed rape crops; however, their efficacy was lower than that of fungicides.

In 2017, the phoma stem canker-affected percentage of winter oilseed rape stems was 1.5-2.8 times higher than in 2015 and 1.0-1.6 times higher than in 2016. The disease occurrence was favoured by the wet weather in the autumn of 2016 and in the spring of 2017. Kaczmarek et al. (2016) have found that the conduciveness of climate for ascospore release by L. maculans and L. biglobosa increased with increases in temperature and precipitation. In 2017, the phoma stem canker-affected stems accounted for $83.4-97.5 \%$, the disease severity index ranged from 4.72 to 6.06 . Without the use of the bio-preparations, the number of phoma stem canker-affected stems did not differ significantly among the weed control treatments investigated. With the use of the bio-preparations in the mechanical weed control treatment, the number of disease affected stems was significantly $14.5 \%$ and $9.1 \%$ lower than in the thermal and self-regulation weed control treatments. The disease score values for most of the stems tested were 5 (more than $50 \%$ stem perimeter girdled by the disease lesions) and 6 (dead plants), from $24.2 \%$ to $30.9 \%$ and from $25.2 \%$ to $44.0 \%$, respectively. In the mechanical weed control plots without bio-preparations, significantly $40.9 \%$ lower number of disease affected stems was determined than in the thermal weed control treatment. In the mechanical and self-regulation weed control treatments with the use of the bio-preparations, compared with the thermal weed control treatment, significantly $48.1 \%$ and $34.4 \%$ lower number of stems with a disease score value $4(25-50 \%$ of the stem perimeter girdled with the disease lesions) was found. The use of the bio-preparations compared with no use did not have marked effect on the occurrence of phoma stem canker in the winter oilseed rape crop tested.

Verticillium wilt damage. In 2015, at the winter oilseed rape growth stage $\mathrm{BBCH} 85$ the verticillium wiltaffected stems accounted for $16.7-45.0 \%$ (Fig. 2). In the study by Spitzer and Matušinsky (2017), the verticillium wilt-affected rape stems was from $12 \%$ to $41 \%$. Both with the use and without the use of the bio-preparations, significantly higher number of verticillium wilt-damaged stems was established in the mechanical weed control treatment, compared with the thermal and self-regulation treatments by respectively 2.7 times and 1.9 and 1.6 times. The use of the bio-preparations, compared with no use, significantly by $27.8 \%$ reduced the number of verticillium wilt-affected oilseed rape stems only in the mechanical weed control plots.

In 2016, the number of verticillium wiltaffected oilseed rape stems was 1.1-3.6 times higher than in the dry year 2015. In 2016, verticillium wiltaffected stems accounted for 35.0-59.2\%. Dunker et al. (2008) have indicated that climatic conditions appear to be responsible for the strong delay in fungal invasion of plants in the field. The number of the disease-affected

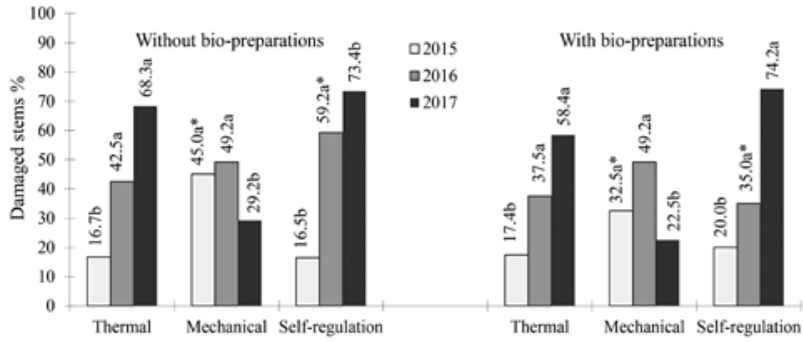

Note. The differences between the averages of treatments of factor A at one level of factor B, marked by not the same letter $(\mathrm{a}, \mathrm{b})$ and between the averages of treatments of factor $\mathrm{B}$, marked by an asterisk are significant $(P<0.05)$.

Figure 2. The incidence of verticillium wilt in the winter oilseed rape crop (2015-2017)

stems did not differ significantly among the different weed control treatments. The use of the bio-preparations, compared with no use, significantly by $40.9 \%$ reduced the number of veticillium wilt-affected stems only in the self-regulation weed control plots.

In the wet and cooler year 2017, in the thermal and self-regulation weed control plots, there were more disease-affected stems than in 2015 by $3.4-4.4$ times and in 2016 by respectively $1.2-2.1$ times. In the mechanical weed control plots, in 2017 there were found fewer verticillium wilt-affected stems than in 2015 and 2016 by respectively $1.4-1.5$ times and by $1.7-2.2$ times. In 2016 , the verticillium wilt-affected oilseed rape stems accounted for $22.5-74.2 \%$. Bot with the use of the biopreparations and without, significantly lower number of verticillium wilt-affected stems was recorded in the mechanical weed control treatment compared with the thermal and self-regulation plots by respectively 2.3 and 2.5 times and 2.5 and 3.3 times.

Dark leaf and pod spot damage. The severity of dark leaf and pod spot on the siliques of winter oilseed rape differed among the experimental years (Fig. 3). In 2015 , the severity of dark leaf and pod spot on siliques was established to be 2.0-4.8 times higher than in 2016 and 4.7-8.8 times higher than in 2017. It is likely that the incidence of dark leaf and pod spot (from 8.69\% to $24.0 \%$ ) in the winter oilseed rape crop in 2015 was favoured by warmer and wetter than usual winter and early spring period and the resulting denser and more luxuriant crop stand.

Without the use of the bio-preparations in 2015 in the thermal weed control plots, the severity of dark leaf and pod spot on siliques was established to be significantly by $41.7 \%$ and $43.9 \%$ lower than in the mechanical and self-regulation weed control plots. Experiments conducted by Mockevičienè (2017) showed that dark leaf and pod spot disease incidence was the lowest in the oilseed rape crop where water steam

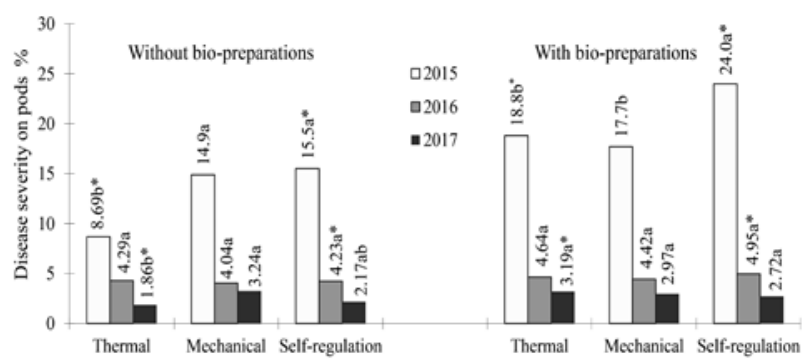

Note. The differences between the averages of treatments of factor A at one level of factor B, marked by not the same letter $(\mathrm{a}, \mathrm{b})$ and between the averages of treatments of factor $\mathrm{B}$, marked by an asterisk are significant $(P<0.05)$.

Figure 3. The severity of dark pod spot on winter oilseed rape pods (2015-2017) 
was used for weed control. With the use of the biopreparations, in the thermal and mechanical weed control treatments, compared with the self-regulation treatment, the severity of dark leaf and pod spot was shown to be significantly by respectively $21.7 \%$ and $26.2 \%$ lower. The use of the bio-preparations, compared with no use, significantly increased dark leaf and pod spot severity on oilseed rape siliques in the thermal and self-regulation weed control plots by respectively 2.2 and 1.5 times. Brazauskiene et al. (2011 a) have documented that the incidence of dark leaf and pod spot on winter oilseed rape siliques was higher only in the years conducive to the occurrence of the disease. In dry years, the disease severity on siliques was low, less than $2.0 \%$ of the area of siliques was damaged by the disease.

In 2016, dark leaf and pod spot severity on siliques ranged from $4.04 \%$ to $4.95 \%$. There were found no significant differences in the dark leaf and pod spot incidence among the different weed management treatments investigated. The use of the bio-preparations, compared with no use, significantly by $17.0 \%$ increased the severity of dark leaf and pod spot on oilseed rape siliques only in the self-regulation weed control plots.

In 2017, the severity of dark leaf and pod spot on siliques ranged from $1.86 \%$ to $3.24 \%$. Without the use of the bio-preparations in the thermal weed control plots, dark leaf and pod spot severity on oilseed rape siliques was determined to be significantly by $42.6 \%$ lower than in the mechanical weed control plots. With the use of the bio-preparations, the incidence of the dark leaf and pod spot did not differ significantly among the different weed control treatments. The use of the bio-preparations, compared with no use, significantly by $71.5 \%$ increased the severity of dark leaf and pod spot only in the mechanical weed control treatment.

Rapeseed yield. In 2015, the highest rapeseed yield was produced in the mechanical weed control treatment (inter-row cultivation), applied in the autumn at a 3-4 leaf growth stage of winter rape and in the spring after resumption of vegetation (Table 2). Compared with the thermal and self-regulation treatments, the rapeseed yield was by $28.0 \%$ and $32.6 \%$ higher without the use of the bio-preparations and by $11.7 \%$ and $56.8 \%$ higher with the use of the bio-preparations. The use of bio-preparations enhanced the efficacy of thermal weed control treatment, where rapeseed yield was significantly $40.4 \%$ higher than in the self-regulation treatment. Kierzek et al. (2008) have found that inter-row cultivation in the winter oilseed rape crop in the autumn (at 4 leaf growth stage) and in the spring is more effective than a single cultivation in the autumn at 4 leaf stage. According to their research results, rapeseed yield was also influenced by the meteorological conditions and the quality of inter-row cultivation. The use of the bio-preparations, compared with no use, significantly increased rapeseed yield in the thermal and mechanical weed control treatments by respectively $43.4 \%$ and $25.1 \%$.

In 2016 , rapeseed yield was from 1.5 to 4.6 times lower than in 2015 . This was influenced by the lower over winter survival rate of oilseed rape plants, a rainy July with $162.9 \mathrm{~mm}$ rainfall and higher incidence of phoma stem canker and verticillium wilt in the rapeseed crop. There were no significant differences in rapeseed yield among the different weed control treatments without the use of bio-preparations. In the treatments with the use of the bio-preparations, significantly higher rapeseed yield was produced in the self-regulation control plots, where it was by respectively $51.5 \%$ and $100 \%$ higher than in the thermal and mechanical weed control plots. In the thermal weed control treatment, the rapeseed yield was significantly $32.0 \%$ higher than in the mechanical weed control treatment. In the self-regulation weed control treatment, the application of the bio-preparations gave a significant $51.5 \%$ rapeseed yield increase, compared with the treatment without the bio-preparations.

In 2017, rapeseed yield was from 4.4 to 13.8 times lower than in 2015 and from 1.2 to 9.1 times lower than in 2016. This can be accounted for by the fact that in April, which received twice as much rainfall as normal, in part of the winter oilseed rape crop area the soil became waterlogged. In addition, the crop was severely infested with phoma stem canker and verticillium wilt. In the self-regulation plots, the rapeseed yield was significantly lower than in the thermal and mechanical weed control treatments by respectively 3.2 and 4.2 times without the use of the bio-preparations and by 3.0 and 3.6 times lower with the use of the bio-preparations. The bio-preparations used, compared with the treatments without them, did not have significant effect on rapeseed

Table 2. The seed yield of winter oilseed rape (2015-2017)

\begin{tabular}{|c|c|c|c|c|}
\hline \multirow{2}{*}{$\begin{array}{c}\text { Weed control } \\
\text { method } \\
(\text { factor } \mathrm{A})\end{array}$} & \multirow{2}{*}{$\begin{array}{l}\text { Application of } \\
\text { bio-preparations } \\
\text { (factor B) }\end{array}$} & \multicolumn{3}{|c|}{$\begin{array}{l}\text { Seed yield } \\
\mathrm{kg} \mathrm{ha}^{-1}\end{array}$} \\
\hline & & 2015 & 2016 & 2017 \\
\hline Thermal & $\begin{array}{l}\text { without application } \\
\text { with application }\end{array}$ & $\begin{array}{l}1430 \mathrm{~b}^{*} \\
2050 \mathrm{~b}^{*}\end{array}$ & $\begin{array}{l}590 \mathrm{a} \\
660 \mathrm{~b}\end{array}$ & $\begin{array}{l}320 \mathrm{a} \\
330 \mathrm{a}\end{array}$ \\
\hline Mechanical & $\begin{array}{c}\text { without application } \\
\text { with application }\end{array}$ & $\begin{array}{l}1830 a^{*} \\
2290 a^{*}\end{array}$ & $\begin{array}{l}500 \mathrm{a} \\
500 \mathrm{c}\end{array}$ & $\begin{array}{l}420 \mathrm{a} \\
400 \mathrm{a}\end{array}$ \\
\hline Self-regulation & $\begin{array}{l}\text { without application } \\
\text { with application }\end{array}$ & $\begin{array}{l}1380 \mathrm{~b} \\
1460 \mathrm{c}\end{array}$ & $\begin{array}{l}660 \mathrm{a}^{*} \\
1000 \mathrm{a}^{*}\end{array}$ & $\begin{array}{l}100 \mathrm{~b} \\
110 \mathrm{~b}\end{array}$ \\
\hline
\end{tabular}

Note. The differences between the averages of treatments of factor A at one level of factor B, marked by not the same letter (a, b, c) and between the averages of treatments of factor $\mathrm{B}$, marked by an asterisk are significant $(P<0.05)$.

yield. In 2017, negative, strong, statistically significant correlation $\left(r^{2}=0.69, P<0.05\right)$ was determined between verticillium wilt severity and rapeseed yield. In 2015 and 2016 statistically significant relationships between disease abundance and rape seed yield were not observed.

\section{Conclusions}

1. Under the conditions less conducive to the occurrence of phoma stem canker, both thermal and mechanical weed management methods slightly inhibited the spread of the latter disease in the winter oilseed rape experimental plots, compared with the self-regulation weed control treatment. However, under the conditions favourable for the occurrence of phoma stem canker, only mechanical weed control method in combination with the use of bio-preparations showed a tendency to decrease phoma stem canker incidence. In 2016, in the plots applied with the bio-preparations, compared with those without the bio-preparations, a significantly lower number of phoma stem canker-affected stems (by $16.1 \%$ and $40.7 \%$ ) and disease severity index were recorded only in the self-regulation weed control treatment.

2. The thermal weed control provided better prevention of the verticillium wilt occurrence in the winter oilseed rape crop as compared with thermal and self-regulation weed control in 2015 and 2016 . In 2017, significantly, from 2.3 to 3.3 times lower number of verticillium wilt-affected stems was found in the mechanical weed control treatment, compared with the other weed control treatments tested. The biopreparations were shown to reduce the number of the disease-affected stems by on average $11.1-15.6 \%$. 
3. The thermal weed control without the use of the bio-preparations was more effective in preventing the spread of dark leaf and pod spot in the winter oilseed rape crop compared with the other investigated weed control and bio-preparation usage treatments. Higher severity of dark leaf and pod spot on the siliques of winter oilseed rape plants by on average $13.1-79.4 \%$ was recorded in the plots where bio-preparations had been used.

4. Rapeseed yield was significantly higher in the mechanical weed control plots compared with the other investigated weed control methods in 2015. In 2017, mechanical weed control enabled us to get significantly higher rapeseed yield as compared with self-regulation. However, in 2016 significantly higher rapeseed yield was produced in the plots where selfregulation weed control in combination with the use of the bio-preparations was applied compared with that in the other investigated treatments. In 2015, the bio-preparations were shown to significantly increase rapeseed yield in the thermal and mechanical weed control plots by $43.4 \%$ and $25.1 \%$, respectively, and in 2016 - in the self-regulation plots by $51.5 \%$.

5. Negative, strong, statistically significant correlation $\left(r^{2}=0.69, P<0.05\right)$ was identified between the verticillium wilt severity in the winter oilseed rape crop and rapeseed yield in 2017.

\section{Acknowledgements}

The research was funded by a grant (No. SIT8/2015) from the Research Council of Lithuania.

Received 12042018 Accepted 21092018

\section{References}

1. Aubertot J. N., West J. S., Bousset-Vaslin L., Salam M. U., Barbetti M. J., Diggle A. J. 2006. Improved resistance management for durable disease control: a case study of phoma stem canker of oilseed rape (Brassica napus). European Journal of Plant Pathology, 114: 91-106. https://doi.org/10.1007/s10658-005-3628-Z

2. Bankina B., Gaile Z., Balodis O., Paura. L., Kokina I. 2012. Possibilities for integrated control of winter oilseed rape diseases in Latvia. EPPO Bulletin, 42 (3): 560-567. https://doi.org/10.1111/epp.2601

3. Berg G., Dixelius Ch., Happstadius I. 2006. Verticillium wilt in Sweden - incidence, field scoring and importance. Proceedings of the meeting Integrated Control in Oilseed Crops at Poznań, Poland. IOBC/WPRS Bulletin, 29 (7): 355.

4. Błaszczyk L., Siwulski M., Sobieralski K., Lisiecka J., Jedryczka M. 2014. Trichoderma spp. - application and prospects for use in organic farming industry. Journal of Plant Protection Research, 54 (4): 309-317. https://doi.org/10.2478/jppr-2014-0047

5. Brazauskienè I., Petraitienè E., Povilionienè E. 2007. Investigation of indicators of phoma stem canker (Leptosphaeria maculants) epidemiology and disease incidence in winter rape. Zemdirbyste-Agriculture, 94 (3): 176-188 (in Lithuanian).

6. Brazauskienè I., Petraitienè E., Brazauskas G. Semaškienè R. 2011 (a). Medium-term trends in dark leaf and pod spot epidemics in Brassica napus and Brassica rapa in Lithuania. Journal of Plant Diseases and Protection, 118 (6): 197-207. https://doi.org/10.1007/BF03356404

7. Brazauskienè I., Piliponytė A., Petraitienẻ E., Brazauskas G. 2011 (b). Diversity of Leptosphaeria maculants / L. biglobosa species complex and epidemiology of phoma stem canker on oilseed rape in Lithuania. Journal of Plant Pathology, 93 (3): 577-585.

8. Brazauskienè I., Petraitienè E., Piliponyte A. Brazauskas G. 2012. The peculiarities of phoma stem canker (Leptosphaeria maculants / L. biglobosa complex) infections in winter and spring oilseed rape (Brassica napus L.). Zemdirbyste-Agriculture, 99 (4): 379-386.

9. Brazienè Z., Vasinauskienè R. 2011. The influence of damp water steam on the incidence of fungal diseases and aphides in sugar beet crop. Žemès ūkio mokslai, 18 (2): 53-58 (in Lithuanian).

https://doi.org/10.6001/zemesukiomokslai.v18i2.2193
10. Bulgari R., Cocetta G., Trivellini A., Vernieri P., Ferrante A. 2015. Biostimulants and crop responses: a review. Biological Agriculture and Horticulture, 31 (1): 1-17. https://doi.org/10.1080/01448765.2014.964649

11. Cai X., Huang Y., Jiang D., Fitt B. D. L., Li G., Yang L. 2018. Evaluation of oilseed rape seed yield losses caused by Leptoshaeria biglobosa in central China. European Journal of Plant Pathology, 150: 179-190. https://doi.org/10.1007/s10658-017-1266-x

12. Conn K. L., Tewari J. P., Awasthi R. P. 1990. A disease assessment key for Alternaria black spot in rape seed and mustard. Canadian Plant Disease Survey, 70: 19-22.

13. Dabkevičius Z., Brazauskienè I. 2007. Augalu patologija. Lithuanian Institute of Agriculture, 493 p. (in Lithuanian).

14. Dunker S., Keunecke H., Steinbach P., Von Tiedemann A. 2008. Impact of Verticillium longisporum on yield and morphology of winter oilseed rape (Brassica napus) in relation to systemic spread in the plant. Journal of Phytopathology, 156: 698-707. https://doi.org/10.1111/j.1439-0434.2008.01429.x

15. Fernando W. G. D., Zhang X., Amarasinghe C. C. 2016 Detection of Leptosphaeria maculans and Leptosphaeria biglobosa causing blackleg disease in canola from Canadian canola seed lots and dockage. Plants, 5 (1): E12. https://doi.org/10.3390/plants5010012

16. Hegewald H., Koblenz B., Wensch-Dorendorf M., Christen O. 2017. Yield, yield formation, and blackleg disease of oilseed rape cultivated in high-intensity crop rotation. Archives of Agronomy and Soil Science, 63 (13): 1785-1799. https://doi.org/10.1080/03650340.2017.1307508

17. Jakiene E. 2013. The effect of the microelement fertilizers and biological preparation Terra Sorb Foliar on spring rape crop. Žemès ūkio mokslai, 20 (2): 75-83. https://doi.org/10.6001/zemesukiomokslai.v20i2.2687

18. Jakienė E., Spruogis V. 2015. Biological products and bioorganic fertilizer use in sugar beet. Žemès ūkio mokslai, 22 (3): 107-120 (in Lithuanian). https://doi.org/10.6001/zemesukiomokslai.v22i3.3152

19. Kaczmarek J., Kedziora A., Brachaczek A., LatundeDada A. O., Dakowska S., Karg G., Jedryczka M. 2016. Effect of climate change on sporulation of the teleomorphs of Leptosphaeria species causing stem canker of brassicas. Aerobiologia, 32: 39-51. https://doi.org/10.1007/s10453-015-9404-4

20. Kierzek R., Głowacki G., Kaczmarek S. 2008. Mechanical methods of wee control in winter oilseed rape. Journal of Research and Applications in Agricultural Engineering, 53 (3): 138-140.

21. Kumar D., Maurya N., Kumar Bharati Y., Kumar A., Kumar K., Srivastava K., Chand G., Kushwaha Ch., Kumar Singh S., Kumar Mishra R., Kumar A. 2014. Alternaria blight of oilseed Brassicas: a comprehensive review. African Journal of Microbiology Research, 8 (30): 2816-2829. https://doi.org/10.5897/AJMR2013.6434

22. Kurowski T. P., Majchrzak B., Kowalska E. 2009. The effectiveness of the biological control of clubroot (Plasmodiophora brassicae) in Brassicaceae plants. Phytopathologia, 52: 5-12.

23. Kuusk A. K., Happstadius I., Zhou L., Steventon L. A., Giese H., Dixelius C. 2002. Presence of Leptosphaeria maculans group A and group B isolates in Sweden. Journal of Phytopathology, 150: 349-356. https://doi.org/10.1046/j.1439-0434.2002.00764.x

24. Lelešius E., Statkevičiūtè G., Petraitienè E. 2016. The prevalence of Verticillium wilt in oilseed rape in Lithuania. Communications in Agricultural and Applied Biological Sciences, 81 (2): 43-49.

25. Liu S. Y., Liu Z., Fitt B. D. L., Evans N., Foster S. J., Huang Y. J., Latunde-Dada A. O., Lucas J. A. 2006. Resistance to Leptosphaeria maculants (phoma stem canker) in Brassica napus (oilseed rape) induced by L. bilobosa and chemical defence activators in field and controlled environments. Plant Phatology, 55 (3): 401-412. https://doi.org/10.1111/j.1365-3059.2006.01354.x

26. Liu Z., Latunde-Dada A. O., Hall A. M., Fitt B. D. L. 2014. Phoma stem canker disease on oilseed rape (Brassica napus) in China is caused by Leptosphaeria biglobosa 'brassicae' European Journal of Plant Pathology, 140: 841-857. https://doi.org/10.1007/s10658-014-0513-7

27. Mazáková J., Urban J., Zouhar M., Ryšánek P. 2017. Analysis of Leptosphaeria species complex causing phoma leaf and stem canker of winter oilseed rape (Brassica napus) in the Czech Republic. Crop and Pasture Science, 68 (3): 254-264. 
28. Meier U. (ed.). 2001. Growth stages of mono- and dicotyledonous plants: BBCH monograph ( $2^{\text {nd }}$ ed.). $158 \mathrm{p}$.

29. Mockevičienè R. 2017. The influence of non-chemical weed control and biopreparations on the agrocenosis of spring oilseed rape: doctoral dissertation. Aleksandras Stulginskis University, 149 p. (in Lithuanian).

30. Oerke E. C. 2006. Crop losses to pests. Journal of Agricultural Science, 144: 31-43. https://doi.org/10.1017/S0021859605005708

31. Pekarskas J., Gavenauskas A., Dautarte A. 2017. The effect of biological preparation Fertenat on spring wheat productivity and quality. Žemès ūkio mokslai, 24 (1): 10-19 (in Lithuanian). https://doi.org/10.6001/zemesukiomokslai.v24i1.3441

32. Peltzer S. C., Hashem A., Osten V. A., Gupta M. L., Diggle A. J., Riethmuller G. P., Douglas A., Moore J. M., Koetz E. A. 2009. Weed management in wide-row cropping systems: a review of current practices and risks for Australian farming systems. Crop and Pasture Science, 60: 395-406. https://doi.org/10.1071/CP08130

33. Raudonius S. 2017. Application of statistics in plant and crop research: important issues. Zemdirbyste-Agriculture, 104 (4): 377-382. https://doi.org/10.13080/z-a.2017.104.048

34. Shrestha S. K., Munk L., Mathur S. B. 2005. Role of weather on Alternaria leaf blight disease and its effect on yield and yield components of mustard. Journal of Nepal Agricultural Research, 6: 62-72. https://doi.org/10.3126/narj.v6i0.3366

35. Sinkevičienè J., Pekarskas J., Krasauskas A. 2015. Influence of biological products on organic winter wheat seed. Žemès ūkio mokslai, 24 (1): 10-19 (in Lithuanian). https://doi.org/10.6001/zemesukiomokslai.v22i2.3112
36. Sirvydas P. A., Kerpauskas P. 2012. Thermal weed control: monograph. Aleksandras Stulginskis University, 328 p. (in Lithuanian).

37. Spitzer T., Matušinsky P. 2017. Detecting pathogens of Verticillium wilt in winter oilseed rape using ELISA and PCR - comparison of the two methods and with visual stand evaluation. Acta Universitatis Agriculturae et Silviculturae Mendelianae Brunensis, 65 (1): 205-210. https://doi.org/10.11118/actaun201765010205

38. Szczepanek M., Wilczewski E., Grzybowski K. 2016. Response of winter oilseed rape (Brassica napus L.) on soil applied humus preparation and foliar potassium fertilizer. Acta Scientiarum Polonorum Agricultura, 15 (4) : 85-94.

39. The World of Organic Agriculture: Statistics and Emerging Trends. 2017. Bonn, Germany, 332 p.

40. Valantin-Morison M., Meynard J. M. 2008. Diagnosis of limiting factors of organic oilseed rape yield. A survey of farmers' fields. Agronomy for Sustainable Development, 28 (4): 527-539. https://doi.org/10.1051/agro:2008026

41. Vasinauskienè R., Brazienè Z. 2017. Control of pests in the sugar beet crop using the damp water steam. Optimization of Ornamental and Garden Plant Assortment, Technologies and Environment, 8 (13): 89-96.

42. Walters D. 2009. Disease control in crops: biological and environmentally-friendly approaches. Wiley-Blackwell, 280 p. https://doi.org/10.1002/9781444312157

43. WRB. 2014. World reference base for soil resources 2014. World soil resources reports No. 106. FAO, Rome.

44. Žemès ūkio augalu kenkejjai, ligos ir ju apskaita / compiled by J. Surkus, I. Gaurilčikienè. 2002. Lithuanian Institute of Agriculture, 346 p. (in Lithuanian).

ISSN 1392-3196 / e-ISSN 2335-8947

Zemdirbyste-Agriculture, vol. 105, No. 4 (2018), p. 331-338

DOI 10.13080/z-a.2018.105.042

\title{
Piktžolių kontrolès necheminių būdų įtaka ligų plitimui ekologiniame žieminių rapsų pasèlyje
}

\author{
A. Marcinkevičienè ${ }^{1}$, R. Velička ${ }^{1,2}$, L. M. Butkevičienè $\dot{1}^{1,2}$, M. Keidan ${ }^{1}$, R. Pupaliené ${ }^{1}$, \\ Z. Kriaučiūnienè $\dot{e}^{1,2}$, R. Kosteckas², S. Čekanauskas ${ }^{2}$, S. Raudonius ${ }^{1}$ \\ ${ }^{1}$ Aleksandro Stulginskio universitetas \\ ${ }^{2}$ Aleksandro Stulginskio universiteto Bandymų stotis
}

\section{Santrauka}

Rapsus auginant ekologinès žemdirbystès sąlygomis yra didelè piktžolių, kenkėjų ir ligų plitimo rizika, todèl gaunamas mažas rapsų sẻklų derlingumas. Tyrimų tikslas - nustatyti piktžolių necheminių kontrolès būdų (terminio, mechaninio ir stelbimo) ịtaka grybinių ligų (fomozès, verticiliozès ir juodosios dèmètligès) plitimui žieminio rapso (Brassica napus L.) pasèlyje bei rapsų sèklų derlingumui ekologineje žemdirbystėje. Lauko eksperimentas atliktas 2014-2017 m. Aleksandro Stulginskio universiteto Bandymu stotyje. Dirvožemis - karbonatingas giliau glejjiškas išplautžemis (IDg4-k). Taikyti necheminiai piktžolių kontrolès būdai (A veiksnys): 1) terminis (drègnuoju vandens garu), 2) mechaninis (tarpueiliu purenimas), 3) stelbimas (savireguliacija) ir biologiniai preparatai (B veiksnys): 1) nenaudoti, 2) naudoti. Taikant terminị ir mechaninị piktžolių kontrolès būdą rapsai auginti $48 \mathrm{~cm}$ tarpueiliais, stelbima $-12 \mathrm{~cm}$ tarpueiliais.

Fomozès plitimui mažiau palankiomis sąlygomis ir terminis, ir mechaninis piktžolių kontrolès būdai neesmingai stabdè ligos išplitimą rapsu pasèlyje, palyginti su stelbimo būdo taikymu. Šios ligos plitimui palankiomis sąlygomis rapsu pasėlyje nustatyta mažesnio fomozès plitimo tendencija tik mechaninio piktžolių kontrolès būdą taikant kartu su biologiniais preparatais. $2016 \mathrm{~m}$. panaudojus biologinius preparatus, palyginti su ju nenaudojimu, esmingai 16,1 ir 40,7 \% mažesnis fomozès pažeistų rapsų stiebų kiekis ir ligos pažeidimo indeksas nustatyti tik stelbimo būdo laukeliuose.

2015 ir 2016 m. verticiliozè mažiausiai išplito rapsu pasėlyje, kuriame piktžolès naikintos drègnuoju vandens garu. 2017 m. esmingai (nuo 2,3 iki 3,3 karto) mažesnis verticiliozės pažeistų stiebų kiekis nustatytas mechaninio kontrolès būdo laukeliuose, palyginti su kitais taikytais piktžoliu kontrolès būdais. Vidutiniais duomenimis, biologiniai preparatai nuo 11,1 iki 15,6 \% mažino verticiliozès pažeistų rapsų stiebų kiekį.

Juodoji dèmètligè mažiausiai plito rapsu pasėlyje, kuriame piktžolès naikintos drėgnuoju vandens garu ir nenaudoti biologiniai preparatai, palyginti su kitais taikytais piktžolių kontrolès būdais. Vidutiniais duomenimis, nuo 13,1 iki 79,4\% didesnis juodosios dèmètligès intensyvumas ant rapsu ankštaru nustatytas laukeliuose, kuriuose buvo naudoti biologiniai preparatai. Esmingai didžiausias žieminių rapsų sėklų derlingumas $2015 \mathrm{~m}$. ir esmingai didesnis, palyginus su stelbimo variantu 2017 m., nustatytas taikant mechanini piktžoliu kontrolès būda, $2016 \mathrm{~m}$. taikant stelbimo būdą su biologiniais preparatais. Biologiniai preparatai rapsų sẻklų derlingumą $2015 \mathrm{~m}$. terminio ir mechaninio piktžoliu kontrolès būdu laukeliuose esmingai didino atitinkamai 43,4 ir 25,1\%, $2016 \mathrm{~m}$. stelbimo būdo laukeliuose $-51,5 \%$. Tarp verticiliozès plitimo intensyvumo žieminių rapsų pasèlyje ir sẻklų derlingumo $2017 \mathrm{~m}$. nustatytas neigiamas, stiprus ir esminis koreliacinis ryšys $\left(r^{2}=0,69, P<0,05\right)$.

Reikšminiai žodžiai: biologiniai preparatai, Brassica napus, ekologinė žemdirbystė, ligos, piktžolių kontrolès būdai, sèklų derlingumas. 